Article

\title{
Rapid Excavation and Stability Control of Deep Roadways for an Underground Coal Mine with High Production in Inner Mongolia
}

\author{
Zhengzheng Xie ${ }^{1}$, Nong Zhang ${ }^{1, *}(\mathbb{D})$, Deyu Qian ${ }^{1, *}$, Changliang Han ${ }^{1}$, Yanpei An ${ }^{1}$ \\ and Yang Wang ${ }^{1,2}$ \\ 1 Key Laboratory of Deep Coal Resource Mining, Ministry of Education of China, School of Mines, \\ China University of Mining and Technology, Xuzhou 221116, China; xie_zz@cumt.edu.cn (Z.X.); \\ hanchangliang@cumt.edu.cn (C.H.); anyanpei@cumt.edu.cn (Y.A.); TB15020024B0@cumt.edu.cn (Y.W.) \\ 2 School of Public Policy and Urban Affairs, College of Social Sciences and Humanities, \\ Northeastern University, Boston, MA 02115, USA \\ * Correspondence: zhangnong@cumt.edu.cn (N.Z.); qian@cumt.edu.cn (D.Q.)
}

Received: 4 April 2018; Accepted: 10 April 2018; Published: 12 April 2018

\begin{abstract}
For large underground coal mines producing 10 million tons a year, rapid excavation and stability of deep roadways are pivotal to ensure sustainable, safe, and efficient production. This paper provides a case study of Hulusu Coal Mine in Inner Mongolia, where roadway excavation speed was insufficient to meet production needs. Moreover, deformation in the roofs of the roadways was severe. To achieve rapid excavation and control the stability of deep roadways, a new support system was proposed and constructed in a roadway at a depth of $640 \mathrm{~m}$. The system consisted of long flexible bolts pretensioned to high levels and spaced at large intervals. Roadway excavation and construction of a support system were conducted simultaneously. Field measurements indicated that the new support system effectively controlled deformation and fracture development during excavation and mining. Maximum displacements of the roof during excavation and mining were 10 and $30 \mathrm{~mm}$, respectively. The axial load on bolts surged during excavation as a result of slight deformations caused by excavation operations. This active response of the bolts is beneficial to the prevention of roof deformation during excavation and mining. During mining, fissures propagated up to only a depth of $1.4 \mathrm{~m}$ into the surrounding rock mass. The new support system formed a thick reinforced anchorage zone, which greatly improved the bearing capacity of the roof. Compared with the previous support system, the new system allowed the maximum excavation speed ( $31.5 \mathrm{~m} /$ day) to increase by $85.3 \%$. This successful case provides a practical reference for similar roadway projects.
\end{abstract}

Keywords: underground coal mine; deep roadway; rapid excavation; mining; displacement; long flexible bolts; support; stability control

\section{Introduction}

The shallow coal resources in eastern China are being exhausted, while the development of high-quality coal resources in western China has become a major element of the national energy strategy [1-3]. With the development of China's supply-side structural reform, the large-scale restructuring of coal enterprises further promotes the optimization and integration of coal resources development, especially in Inner Mongolia. As a result, mines with an annual production of 10 million tons are emerging. Therefore, a large number of new roadways need to be excavated every year $[4,5]$. The roadway excavation speed of underground coal mines in western China is generally over $500 \mathrm{~m} /$ month, but this is insufficient to meet production needs. Excavation speed and production 
needs are severely out of balance. Thus, rapid roadway excavation has become the key factor for sustainable, safe, and efficient production in underground coal mines.

Many studies have investigated the imbalance between excavation speed and production needs. For instance, Wang [6] provided a summary on rapid excavation technology and indicated directions for future development. Using site investigations and expert opinions, Wang et al. [7] studied the factors limiting roadway excavation speeds. To improve excavation speed, various studies have been undertaken to improve forecasting and prediction abilities prior to excavation, upgrade the mechanization level of equipment, and optimize construction and labor organization [8-11]. Studies have focused on different geological conditions, including a hard rock, half-coal rock roadway, a roadway with thick top-coal, and coal seams with risks of coal and gas outburst [12-16]. Improvements in the excavation speed of deep roadways must be accompanied by roadway safety and stability. Using empirical approaches, Goel et al. [17] studied the deformation problems associated with poor rock mass in a power tunnel. Zhang et al. [18] studied stress concentration and rock failure in deep multi-seam coal mining. Seedsman [19] discussed failure mechanisms of roadways. Li et al. [20] investigated the effects of in situ stress on roadway stability. Yang et al. [21] applied the universal distinct element code (UDEC) to simulate the large deformation failure mechanism of a deep soft rock roadway. Li et al. [22] presented the coupling support technology of a double yielding shell for a soft rock roadway under high stress. Ding et al. [23] improved the design for large parallel tunnels. Shen et al. [24] conducted a comprehensive field monitoring study on roadway failure in an underground coal mine in Australia using a system that integrated seismicity, stress, and displacement monitoring. These studies summarize extensive research on the theory and technology of controlling the surrounding rock mass in roadways. Most of them have focused on roof safety and strengthening reinforcements after roadway failure. However, few studies have focused on the initial support system constructed in a roadway and the stability it provides. In addition, the rapid excavation and stability of deep roadways have yet to be studied synthetically. This study puts forward a new design for a roadway reinforcement system and examines the rapid excavation and stability of deep roadways in Hulusu Coal Mine, in Ordos City, Inner Mongolia, China.

Hulusu has an annual production of 13 million tons. Production requires the construction of $900 \mathrm{~m}$ of roadways per month. However, the average roadway excavation speed is only at $500 \mathrm{~m} / \mathrm{month}$. Excavation speed and production needs are severely out of balance. In addition, large deformation (reaching about $900 \mathrm{~mm}$, Figure 1) and failure of roadway roofs during mining pose serious threats to safety and production. Taking into consideration the imbalance of excavation speed and production needs and the stability issues of deep roadways, we designed a roadway reinforcement system allowing for rapid excavation and, hence, high production rates. The design is reported in this study, as well as industrial tests and field measurements that were used to evaluate the engineering geological conditions of the roadways. The effectiveness of the new support system is also analyzed and provides a practical reference for the rapid excavation of deep roadways in large underground coal mines.

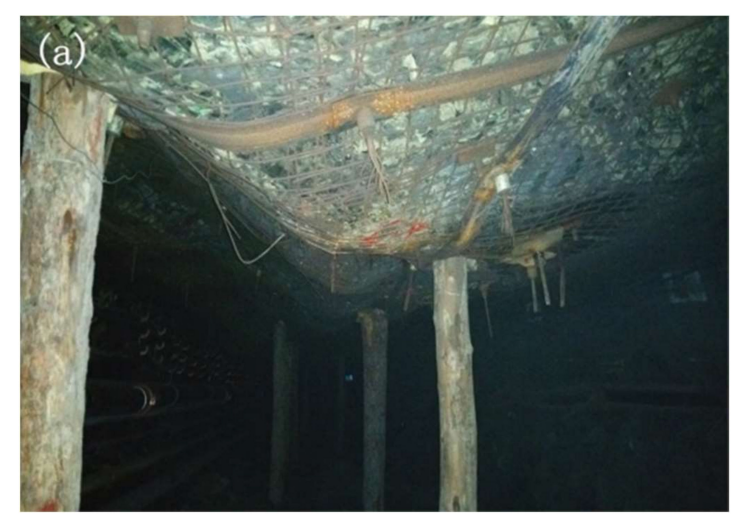

Figure 1. Cont. 

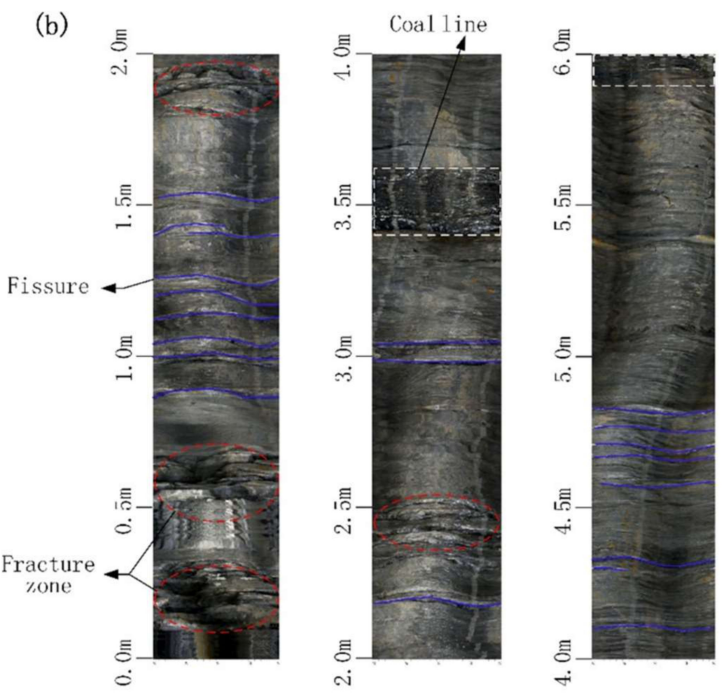

Figure 1. Deformation of roadway after mining: (a) deformation of the roof of the roadway; (b) roof failure. Notes: Roof deformed by up to $900 \mathrm{~mm}$, and fissures extended to a depth of about $4.8 \mathrm{~m}$ from the roof surface.

\section{Engineering Geological Conditions}

Hulusu Coal Mine is located in Ordos City, Inner Mongolia (Figure 2). The mine is divided into eastern and western mining districts. In the eastern district, there are three longwall coal faces (LCFs): LCF 21102, LCF 21103, and LCF 21104. Longwall coal faces in the western district include LCF 21204 and LCF 21205 (Figure 3). LCF 21102 is the first panel to be mined, where upper coal seam No. 2 is being extracted. Seam thickness varies from 1.87 to $3.55 \mathrm{~m}$. The strata are gentle and the dip angle of the seam is generally less than $2^{\circ}$. The seam is located at a depth greater than $640 \mathrm{~m}$. In situ stress measurements indicated vertical $\left(\sigma_{\mathrm{v}}\right)$ and maximum horizontal principal $\left(\sigma_{\mathrm{H}}\right)$ stresses of 22.33 and $15.35 \mathrm{MPa}$, respectively (Table 1 and Figure 3). The horizontal-to-vertical stress coefficient $\left(\lambda=\sigma_{H} / \sigma_{v}=1.5\right)$ is over 1.0. The in situ stress field is dominated by horizontal tectonic stress.

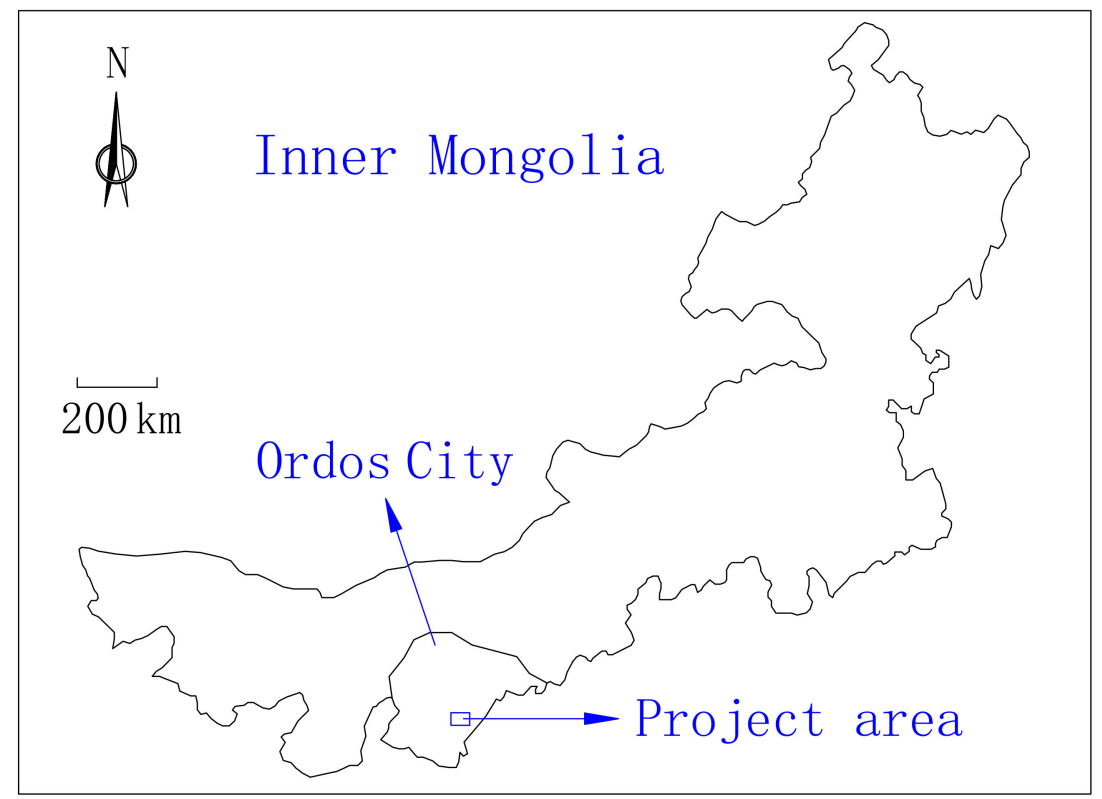

Figure 2. Location of Hulusu Coal Mine in Inner Mongolia. 


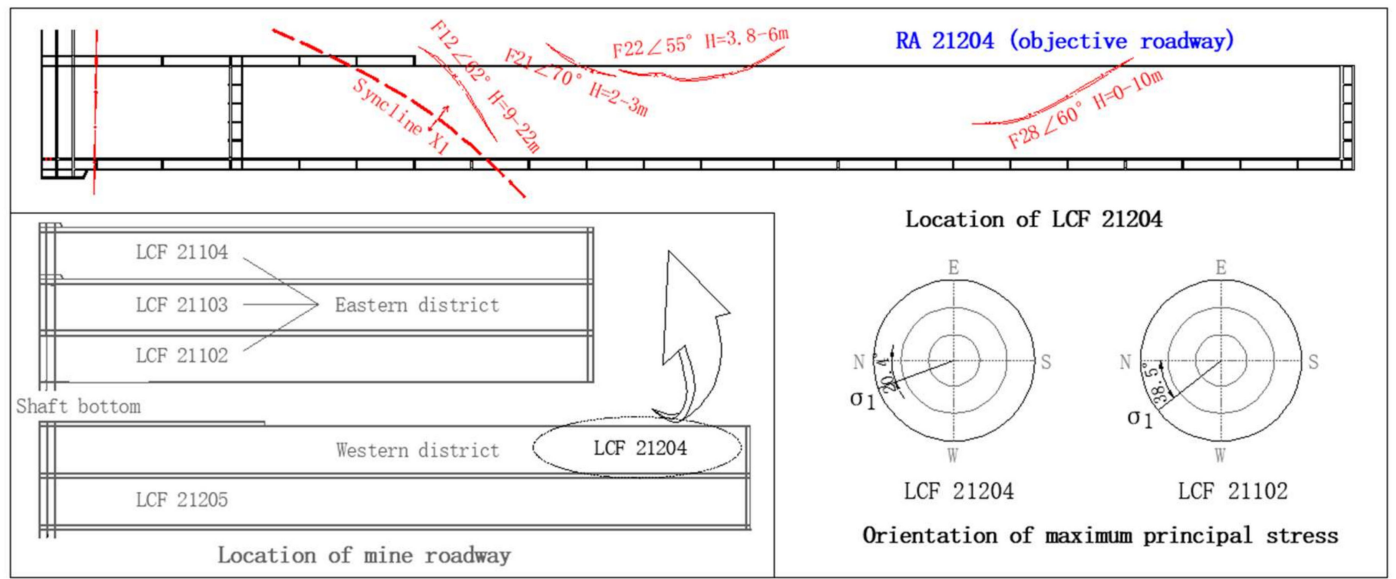

Figure 3. Location and geological condition of the roadway selected for this study. LCF = longwall coal face; RA = return airway.

Table 1. Values of in situ stress measured at two experimental sites in the eastern mining district.

\begin{tabular}{ccccc}
\hline \multirow{2}{*}{ Experiment Site } & \multicolumn{3}{c}{ Stress (MPa) } & \multirow{2}{*}{ Azimuth Angle ( ${ }^{\circ}$ ) } \\
\cline { 2 - 4 } & $\boldsymbol{\sigma}_{\mathbf{H}}$ & $\boldsymbol{\sigma}_{\mathbf{h}}$ & $\boldsymbol{\sigma}_{\mathbf{v}}$ & \\
\hline LCF 21204 & 22.33 & 11.41 & 15.35 & 20.4 \\
LCF 21102 & 18.52 & 9.39 & 15.49 & 38.5 \\
\hline
\end{tabular}

Return airway (RA) 21204 has been selected as the object of this study. It is $5851.7 \mathrm{~m}$ long and runs parallel to auxiliary return airway (ARA) 21204. The excavation of ARA 21204 was stopped after $1228 \mathrm{~m}$. The average excavation speed of RA 21204 is $448 \mathrm{~m} / \mathrm{month}$ (Figure 4), which is insufficient to meet production needs.

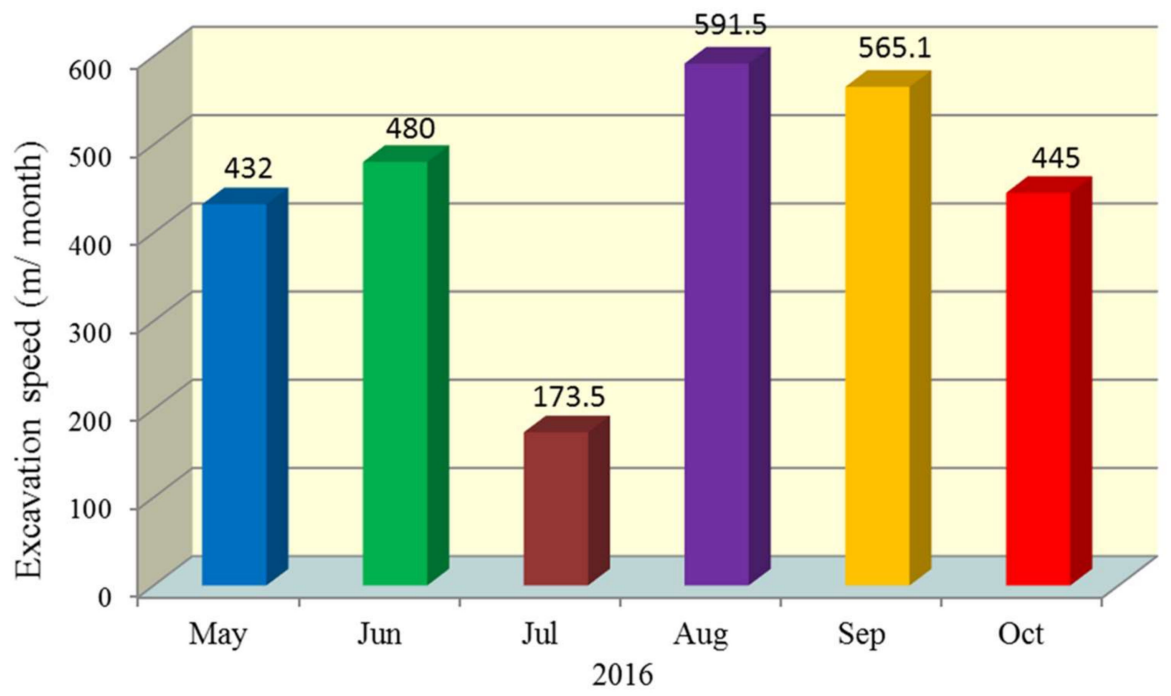

Figure 4. Excavation speed of RA 21204.

There are four faults in the mine: F12, F21, F22, and F28 (Figure 3). F12, which has an average vertical throw of $18 \mathrm{~m}$, is the only fault that has a large influence on roadway excavation.

The stratigraphic column from geological boreholes in RA 21204 is shown in Figure 5. In general, the occurrence of the upper coal seam No. 2 is stable, containing 1-3 layers of gangue material. 
Roof strata are relatively hard, consisting of mostly argillaceous sandstone and fine-grained sandstone, whereas the floor is mainly composed of siltstone and argillaceous sandstone.

\begin{tabular}{|c|c|c|c|}
\hline Stratum type & $\begin{array}{l}\text { Borehole } \\
\text { column }\end{array}$ & $\begin{array}{c}\text { Thickness } \\
\text { (m) }\end{array}$ & $\begin{array}{l}\text { Lithology } \\
\text { description }\end{array}$ \\
\hline \multirow{6}{*}{ Rock roof } & \multirow{6}{*}{\begin{tabular}{|c|c|} 
\\
$\cdots$
\end{tabular}} & 20.2 & Siltstone \\
\hline & & 18. 2 & $\begin{array}{l}\text { Medium-grained } \\
\text { sandstone }\end{array}$ \\
\hline & & 2.6 & $\begin{array}{l}\text { Argillaceous } \\
\text { sandstone }\end{array}$ \\
\hline & & 5.3 & $\begin{array}{l}\text { Fine-grained } \\
\text { sandstone }\end{array}$ \\
\hline & & 3.7 & $\begin{array}{l}\text { Argillaceous } \\
\text { sandstone }\end{array}$ \\
\hline & & $\begin{array}{l}0.3 \\
2.9\end{array}$ & Shale \\
\hline \multirow{5}{*}{ Rock roof } & \multirow{5}{*}{ 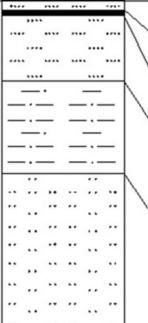 } & $\begin{array}{l}\frac{2.9}{0.7} \\
\end{array}$ & Siltstone \\
\hline & & 0.5 & Coal \\
\hline & & 5.3 & Siltstone \\
\hline & & 7.5 & $\begin{array}{l}\text { Argillaceous } \\
\text { sandstone }\end{array}$ \\
\hline & & 12.8 & $\begin{array}{l}\text { Medium-grained } \\
\text { sandstone }\end{array}$ \\
\hline
\end{tabular}

Figure 5. Stratigraphic column of geological boreholes in RA 21204.

\section{Support System Design}

\subsection{Principles for a Support System Allowing for Rapid Excavation}

The roof was supported previously by six bolts, each $20 \mathrm{~mm}$ in diameter and $2000 \mathrm{~mm}$ in length, combined with three cables, each $17.8 \mathrm{~mm}$ in diameter and $6300 \mathrm{~mm}$ in length. Spacing of bolts and cables was 1000 and $3000 \mathrm{~mm}$, respectively. Pretension in cables was less than $60 \mathrm{kN}$. Despite the high density of the reinforcement array, the roadway failed because the bolts were too short and were unable to restrain initial deformation and subsequent damage in the rock mass. Subsequent excavation and mining activity led to stress redistribution in the rock mass surrounding the roadway. Roof strata delamination extended deep into the surrounding rock, which resulted in the failure of the support system and the roadway. Therefore, a new support system was proposed to control the deformation of the rock surrounding the roadway and improve excavation speed. Integrating field experience and results from field investigations, the new support system took into account the following principles.

(1) Simultaneous excavation and bolt installation. In RA 21204, excavation and bolt installation are carried out using the MB670 bolter miner, which is manufactured by Sandvik Mining and Construction G.m.b.H (Figure 6). When the bolter miner cuts coal, bolts can be installed simultaneously by the roof bolter and the sidewall bolter, preventing initial deformation of the roadway and failure of rock mass. This can maintain the integrity of the rock mass in the roof and improve excavation speed. 
(2) Long flexible bolts. The previous bolt and cable support system was complicated to install and took more than $60 \%$ of the excavation time, which limited excavation speed. Bolts limited deformation in their anchorage zones, but the thickness of the anchorage zones was limited and was unable to prevent roof sag. Cables were insufficiently pretensioned to provide effective reinforcement, and hung loosely in anchorage zones. However, a support system employing long flexible bolts can form a thicker anchorage zone and prevent roof sag. Furthermore, it is simpler to install than the previous system and can lead to improved excavation speed.

(3) High pretension bolting. Active support from long flexible bolts that are pretensioned to high levels can fasten thin layers of roof strata together to form thick reinforced anchorage zones [25]. The level of pretension also determines the speed at which the axial load on the bolt increases. This speed reflects the sensitivity of the bolt to stress changes in the rock mass. Pretension levels also determine the ultimate strength of the bolt [26]. With a higher level of pretension, the bolt is more sensitive to stress changes in the rock mass. It responds more actively, and the axial load increases more rapidly. When slight deformations appear in the rock mass, the strength of a bolt that is pretensioned to high levels increases rapidly. Therefore, the high strength of long flexible bolts could effectively control the delamination of roof strata, which ensures protection from roof collapse. As a result, to provide effective reinforcement to the roof and control the delamination of roof strata, bolts should be pretensioned to high levels.

(4) Large spacing among bolts. In the previous support system, bolts were placed less than $1000 \mathrm{~mm}$ apart, considerably limiting excavation speed. Increasing the spacing is critical to achieving high excavation speeds.

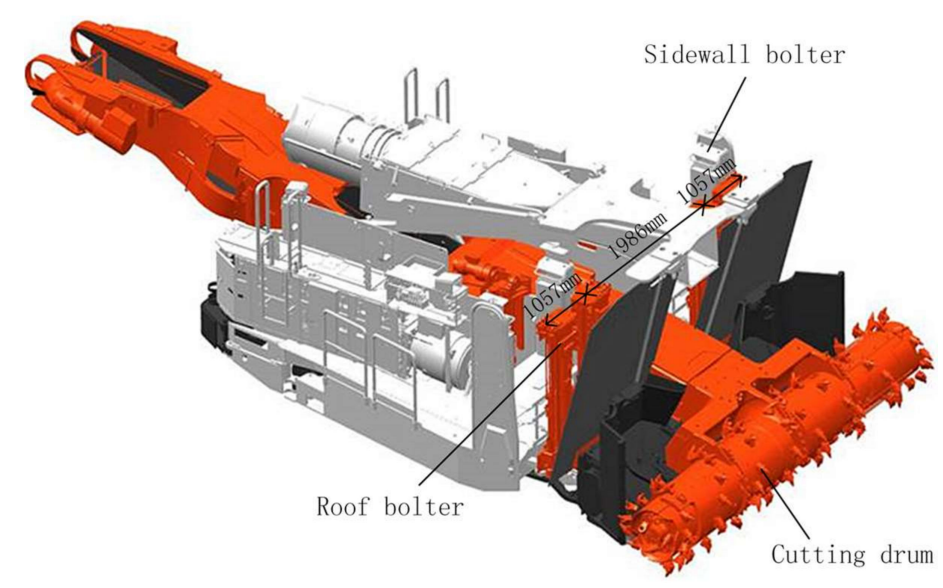

Figure 6. MB670 bolter miner.

\subsection{New Support System}

A new support system, incorporating the considerations above, was proposed and built in RA 21204 in Hulusu Coal Mine. The roadway was $5400 \mathrm{~mm}$ wide and $3200 \mathrm{~mm}$ high. Bolts were installed at 1500-mm intervals along the roadway axis (Figure 7).

(1) The roof was supported by four long flexible bolts, each $21.8 \mathrm{~mm}$ in diameter and $4000 \mathrm{~mm}$ in length, combined with a reinforced steel mesh that was $5400 \mathrm{~mm}$ long and $1600 \mathrm{~mm}$ wide. The mesh was made of welded steel bars of $6.5 \mathrm{~mm}$ in diameter. Flexible bolts were made of high-strength steel rope strands with a yield strength of $1600 \mathrm{MPa}$. Each bolt comprised 19 strands and was installed in the roof with a resin capsule of $23 \mathrm{~mm}$ in diameter and $700 \mathrm{~mm}$ in length. Two types of resin-an SF-type (super-fast anchoring agent) and an MF-type (medium-fast anchoring agent)—were used. To provide effective reinforcement, bolts were pretensioned to 
$200 \mathrm{kN}$ and installed perpendicularly to the roof surface. The four bolts were installed 1057, 1986, and $1057 \mathrm{~mm}$ apart because the roof bolter was not designed to make sideways motion (Figure 6).

(2) The sidewall that was mined was supported with fiberglass-reinforced plastic bolts, each $27 \mathrm{~mm}$ in diameter and $2000 \mathrm{~mm}$ in length, combined with a plastic mesh that was $5400 \mathrm{~mm}$ long and $3200 \mathrm{~mm}$ wide. The pretensioned torque was $100 \mathrm{~N} \cdot \mathrm{m}$ or above. The other sidewall was reinforced by threaded steel bolts, each $20 \mathrm{~mm}$ in diameter and $2200 \mathrm{~mm}$ in length, combined with a diamond-shaped metal mesh that was $5400 \mathrm{~mm}$ long and $3200 \mathrm{~mm}$ wide. The corresponding torque was greater than $150 \mathrm{~N} \cdot \mathrm{m}$.

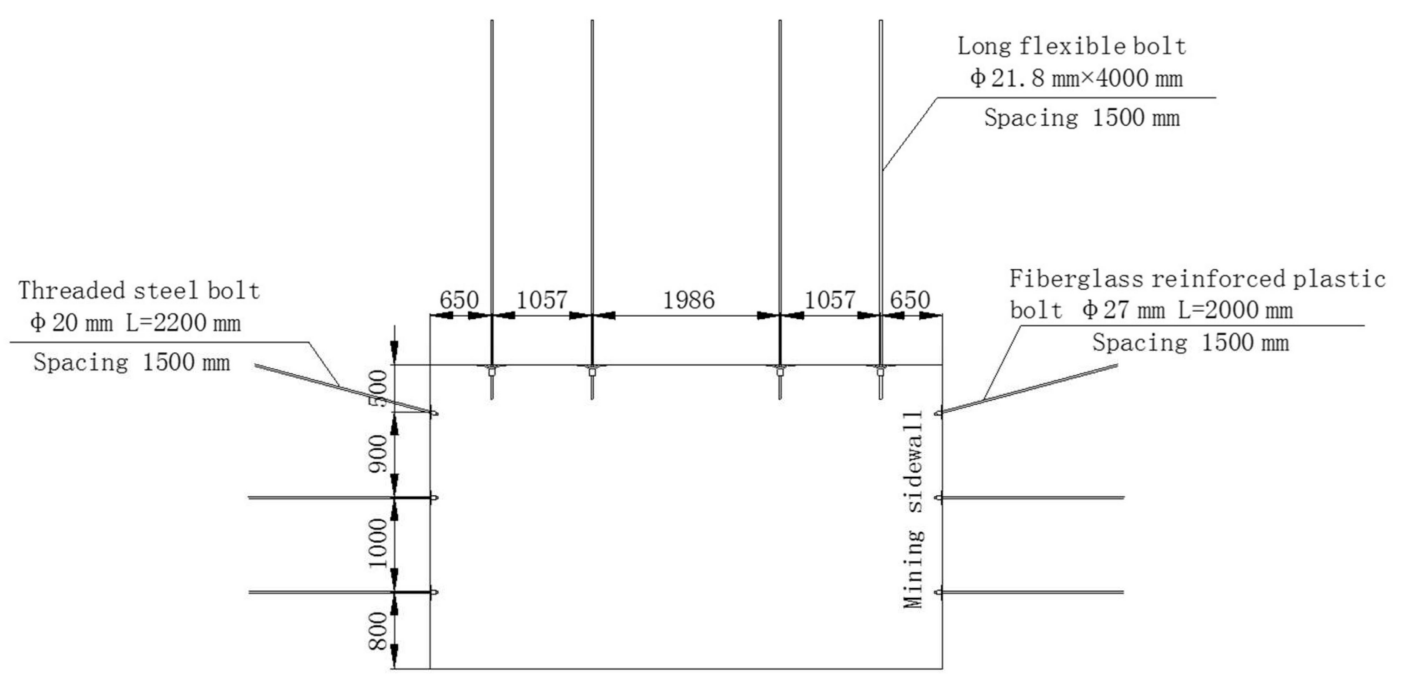

Figure 7. Parameters of the new support system.

\section{Monitoring and Measurement Methods}

The Ordos mining area is characterized by large mining depth, high in situ stress, and insufficient strength in roadway reinforcements. Therefore, for safety reasons, monitoring of the surrounding rock after the installation of a support system is especially important. To analyze the reliability and effectiveness of the new support system, field measurements were carried out during excavation and mining. Axial loads on flexible bolts were measured using digital dynamometers, fracture development in the surrounding rock was monitored with borehole scanners, and surface displacement of the roadway was measured using markers embedded inside the roof, floor, and sidewalls.

\subsection{Axial Load Measurements}

The axial load on flexible bolts was monitored in real-time using the MCS-400 digital dynamometer, which can measure up to $400 \mathrm{kN}$ (Figure 8). This is a vital part of routine monitoring of the roadway reinforcement system and provides information on the working conditions of the bolts. The working principle of the digital dynamometer is shown in Figure 9. The dynamometer consists mainly of sensors, transmitters, and displays. The axial load on bolts causes the sensors to deform. The sensors transform the deformation into a voltage signal, which is converted to a pressure value and displayed on the screen. The internal sensor can save the data every two hours. The collector can download the data when its infrared acquisition port is aligned with the dynamometer window under the light of the miner's lamp. 


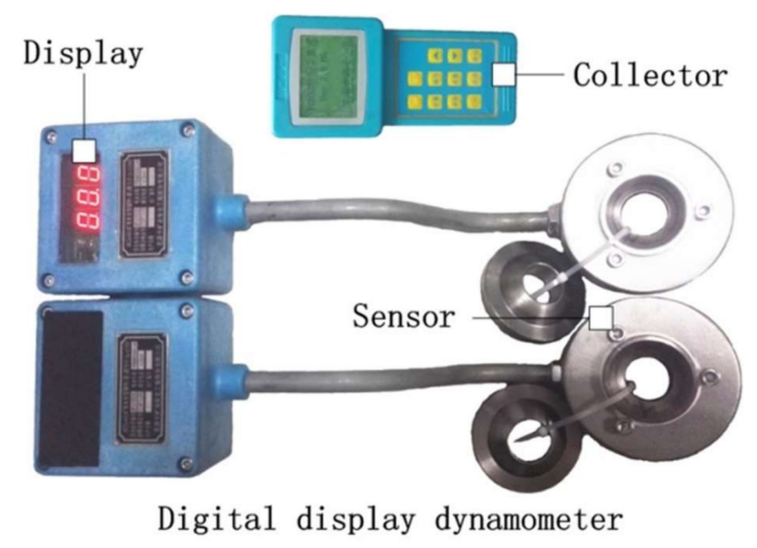

Figure 8. Digital dynamometer.

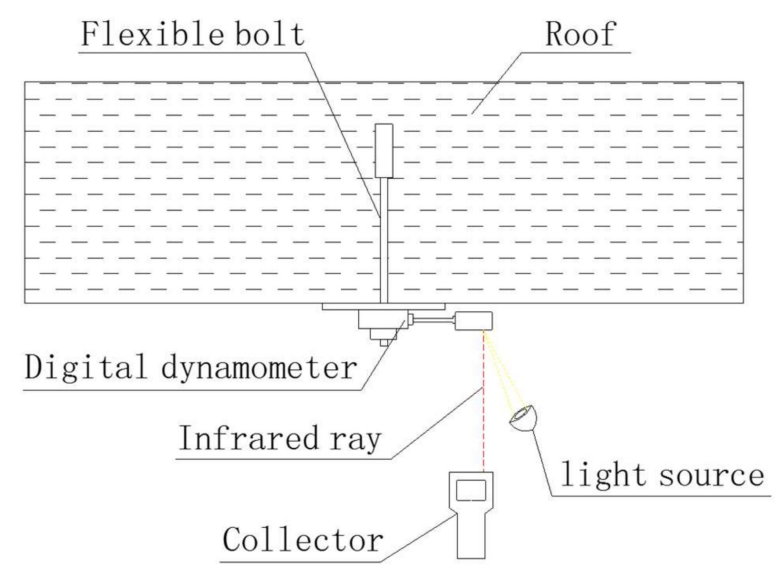

Figure 9. Working principles of the digital dynamometer.

\subsection{Displacement Measurements}

Surface displacement of the roadway was measured using the intersection point method shown in Figure 10. Horizontal markers were fixed on to short bolts at B and C inside the two sidewalls. Vertical markers were fixed on to a short bolt inside the roof (D) and on to a sinker inside the floor (E). Lines $\mathrm{BC}$ and $\mathrm{DE}$ intersect at $\mathrm{A}$. Variations in the lengths of lines $\mathrm{BC}, \mathrm{DE}, \mathrm{AB}$ or $\mathrm{AC}$, and $\mathrm{AD}$ or AE with time were monitored. Each line measures the displacement of a different part of the roadway (Table 2).

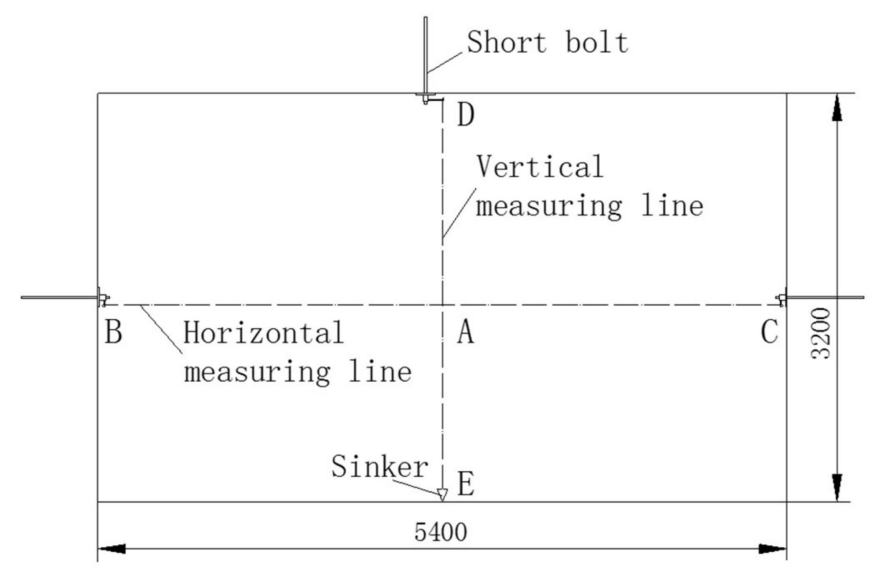

Figure 10. Monitoring sites for surface displacement of the roadway. 
Table 2. Displacement in different parts of the roadway as measured by variations in the lengths of the lines.

\begin{tabular}{ccccccc}
\hline Distance Difference & BC & AB & AC & DE & AD & AE \\
\hline Displacement & Sidewall-to-sidewall & Left sidewall & Right sidewall & Roof-to-floor & Roof & Floor \\
\hline
\end{tabular}

\subsection{Monitoring of Fracture Development}

Fracture development in the surrounding rock was monitored using a ZKXG30 borehole scanner. The scanner is mainly composed of a computer host, a probe, and a depth encoder (Figure 11). A borehole $10 \mathrm{~m}$ in length was drilled into the roof. The probe was inserted into the hole using the connecting rod. The probe has a camera and a three-dimensional high-performance electronic compass that records the azimuthal and dip angle of the borehole. The probe transmits its signals to the host computer via the cable. The host calculates the depth of the probe using signals from the probe and the depth encoder. Video signals are processed. Images are recorded, matched, and spliced, producing panoramic images of the borehole wall.

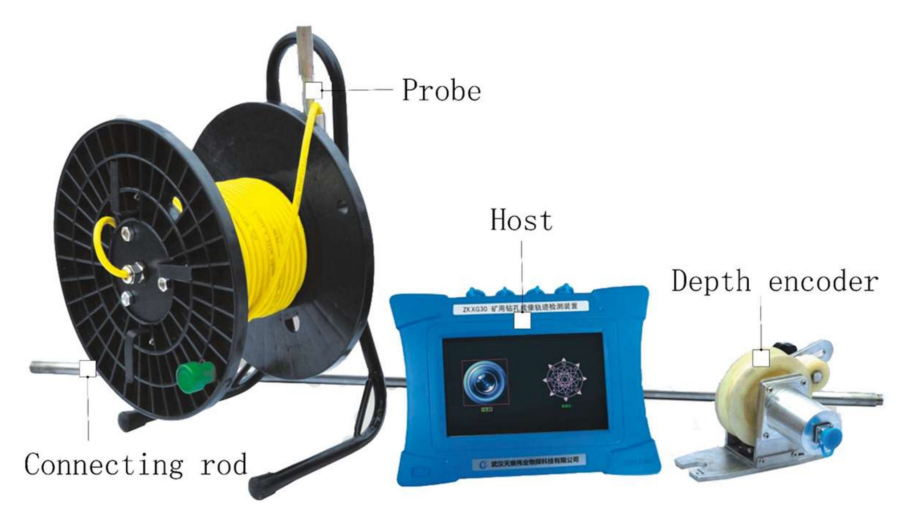

Figure 11. Borehole scanner.

\subsection{Locations of the Field Monitoring Stations}

The locations of the monitoring instruments on a cross-section of the roadway are shown in Figure 12. Instruments were installed at different stations along the roadway and their locations are shown in Figure 13. Table 3 indicates the parameters measured at each of the stations shown in Figure 13. Continuous monitoring was carried out during excavation and mining.

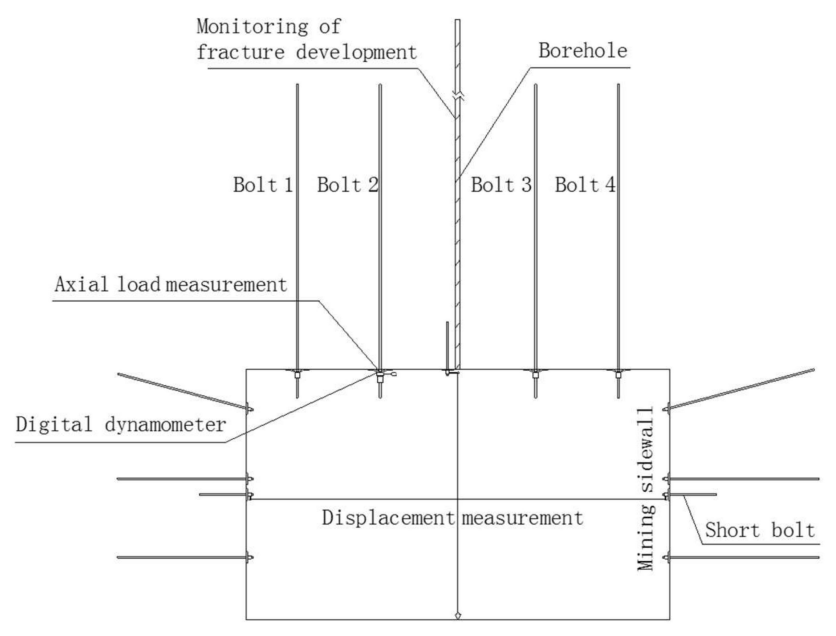

Figure 12. Locations of the monitoring instruments on a cross-section of the roadway. 


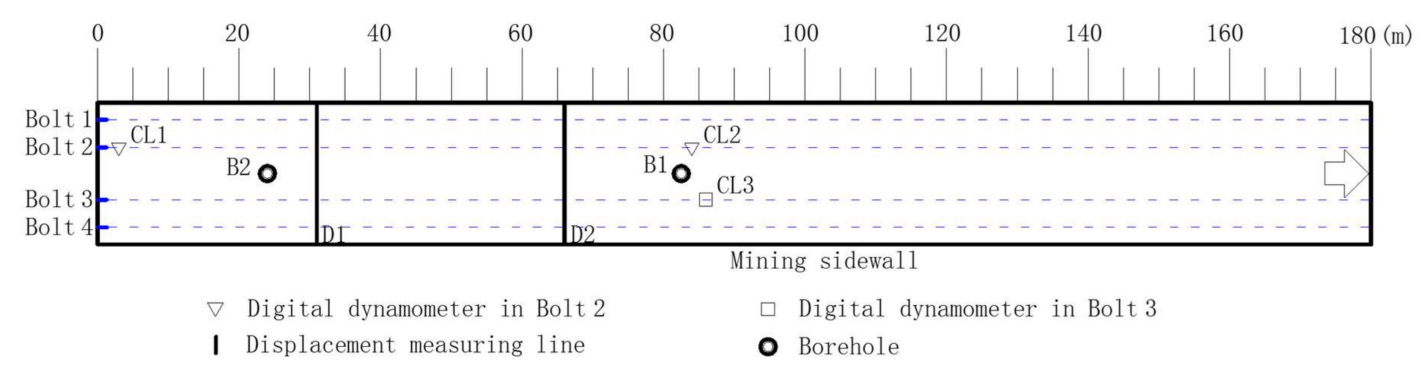

Figure 13. Locations of monitoring stations along RA 21204. Note: The point $0 \mathrm{~m}$ is referred to as $\mathrm{S}$ in the text. Monitoring locations are indicated by their horizontal distance from $\mathrm{S}$.

Table 3. Parameters monitored by stations in Figure 13.

\begin{tabular}{cccc}
\hline Station & $\begin{array}{c}\text { Axial Load of } \\
\text { the Flexible Bolts }\end{array}$ & $\begin{array}{c}\text { Surface } \\
\text { Displacement }\end{array}$ & $\begin{array}{c}\text { Fracture Development of } \\
\text { the Surrounding Rock }\end{array}$ \\
\hline $\begin{array}{c}\text { Excavation } \\
\text { Mining }\end{array}$ & CL1, CL2, CL3 & D1 & B1 \\
\hline
\end{tabular}

\section{Results and Discussion}

\subsection{Monitoring of Axial Load on Flexible Bolts}

Axial loads on flexible bolts were monitored at $\mathrm{S}+3 \mathrm{~m}, \mathrm{~S}+84 \mathrm{~m}$, and $\mathrm{S}+85.5 \mathrm{~m}$ (Figure 13). Figure 14 presents the evolution of axial loads during excavation and mining. From its installation during excavation to its damage by mining operations, the dynamometer recorded more than 1000 sets of data over 3 months, tracking the performance of the support system during the entire excavation and mining process.

Loads on Bolt 2 at Station CL1 evolved over the surge, stable, and fluctuation stages (Figure 14a). The surge stage (OA in Figure 14a) took place during excavation. The enlargement of section OA (inset in Figure 14a) shows that loads increased by $40 \%$ from 267 to $374 \mathrm{kN}$ over $20 \mathrm{~h}$ after bolt installation. Over the next $98 \mathrm{~h}$, loads increased by merely $5.6 \%$ to $395 \mathrm{kN}$. Figure $15 \mathrm{a}$ and Table 4 show that increased loads due to excavation operations were measured up to $125 \mathrm{~m}$ behind the excavation face and that the area within the first $30 \mathrm{~m}$ was severely disturbed by excavation. Over the next two months, during the stable stage (AB), loads changed slightly from 411 to $414 \mathrm{kN}$. During the fluctuation stage (BC), loads fluctuated by $2 \%$ and remained between 410 and $418 \mathrm{kN}$.

The roof inevitably deformed under gravity when the roadway was excavated. The flexible bolts have been pretensioned to up to $200 \mathrm{kN}$. Axial load on the bolts increased rapidly after the bolts were installed during excavation. Loads continued to increase during mining operation because the roof was disturbed by the cutting action of the bolter miner.

Fluctuations in axial loads may be explained by two phenomena. First, the anchorage system could have been functioning only periodically. Gradual damage of the anchorage system during mining and insufficient bonding between the anchoring agent and surrounding rock could have resulted in slight fluctuations of axial loads. Second, severe disturbance from mining could have damaged the roof surface, resulting in inadequate contact between the bolt pallet and the rock surface, decreasing the axial load on bolts. However, loads would rise again when the pallet and the roof surface was further compacted as a result of small deformations of the rock mass in the roof.

The overall features of the evolution of axial loads on Bolt 2 at Station CL2 and Bolt 3 at Station CL3 are consistent with those at CL1 (Figure 14a,b). Figure 14b shows that loads on Bolts 2 and 3 increased sharply over the first $50 \mathrm{~h}$. Loads on Bolt 3 remained stable at $322 \mathrm{kN}$ from the 50th to the 160th hour, while loads on Bolt 2 increased gently over the same period. Table 5 shows that increased loads due to excavation operations were measured up to $157.5 \mathrm{~m}$ behind the excavation 
face, and that the area within the first $56.5 \mathrm{~m}$ was severely disturbed by excavation. During stage $\mathrm{AB}$, the evolution of axial loads at CL2 and CL3 was different from that at CL1. Loads on Bolts 2 and 3 increased gradually between the 220th and the 340th hours because of disturbances from the preparation of the working face. Loads stabilized after this period. During stage $A B$, loads dropped slowly, followed by a rapid rise. Disturbances from excavation were measured over a larger area at Stations CL2 and CL3 than at CL1 because of differences in geological conditions at the stations.

The shallow roof around Stations CL2 and CL3 was gradually damaged as a result of the disturbance from mining of the working face. Loads at Stations CL2 and CL3 decreased slowly since they were located $100 \mathrm{~m}$ from LCF 21204, and the corresponding descending slopes were 0.021 and 0.009 , respectively. Delamination of the roof strata developed as the working face approached the stations. Loads at Stations CL2 and CL3 quickly increased when the working face was at a distance of about $44.5 \mathrm{~m}$, and the corresponding rising slopes were 0.177 and 0.106 , respectively. Loads continued to decrease slightly as the roof broke further due to mining influence.

Axial loads fluctuated within $2 \%$, which indicated excellent performance of the support system during excavation and mining. In addition, differences in geological conditions could have contributed to the differences in roadway stability at $S+3 \mathrm{~m}$ and $\mathrm{S}+85.5 \mathrm{~m}$.

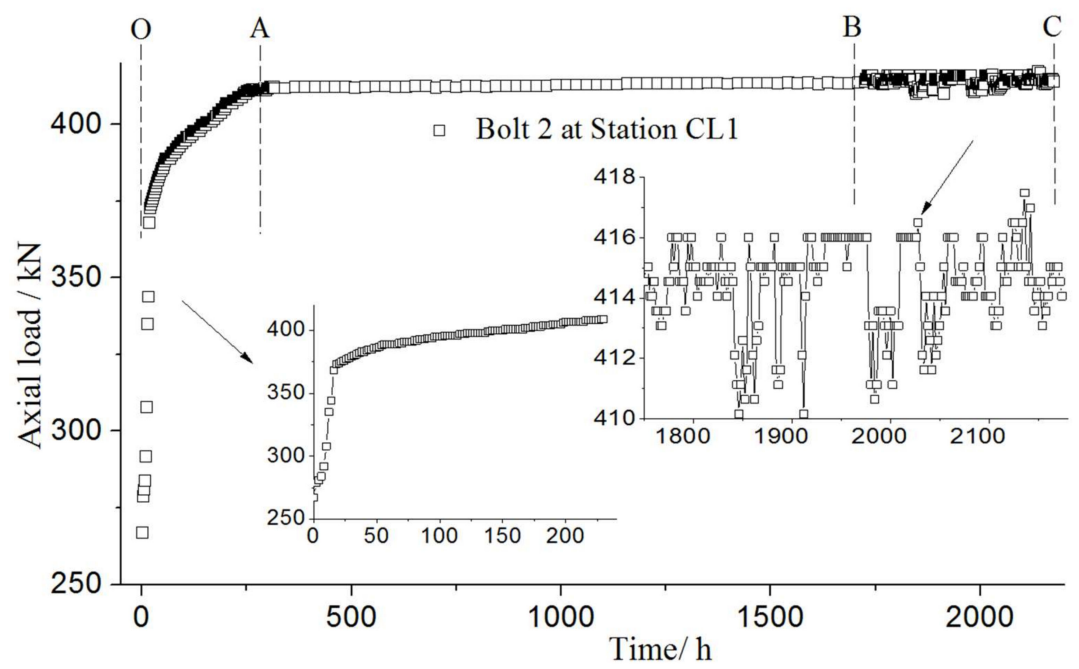

(a)

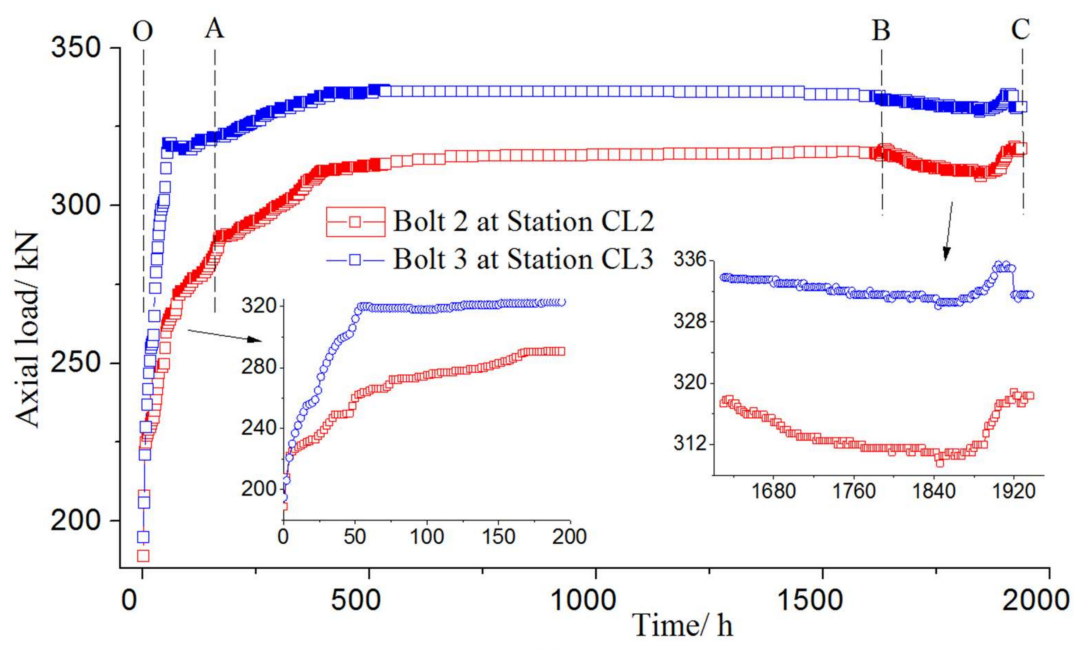

(b)

Figure 14. Axial loads on bolts in the roof at: (a) Station CL1; (b) Stations CL2 and CL3. Note: OA represents the excavation period. $\mathrm{AB}$ represents the period during which the working face was being prepared. $\mathrm{BC}$ marks the mining period. 


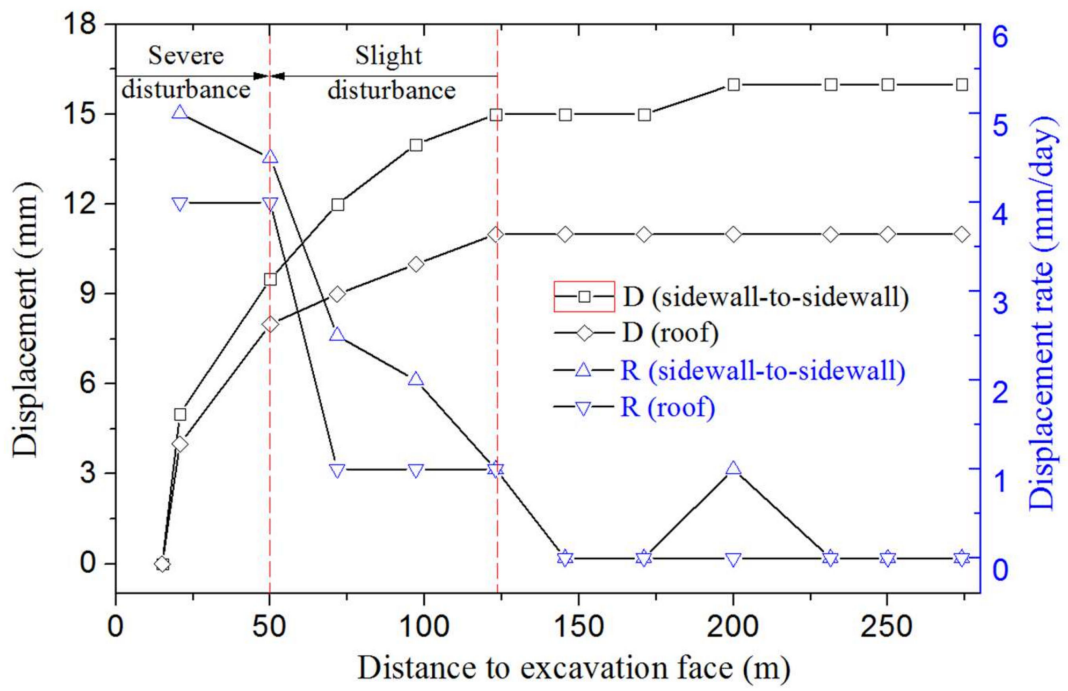

(a)

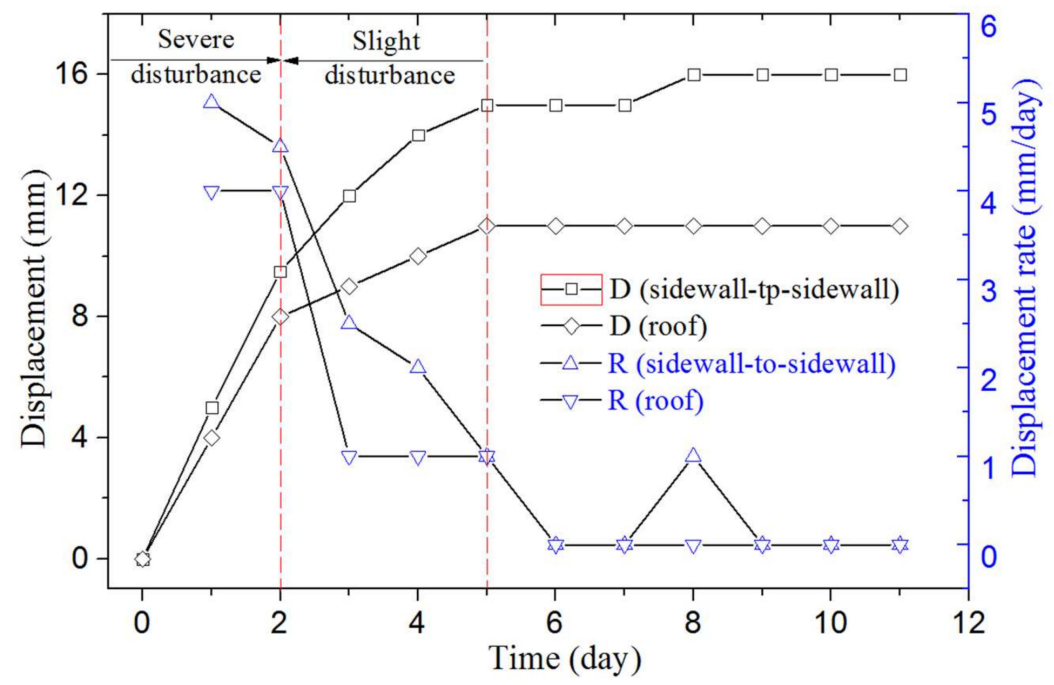

(b)

Figure 15. Surface displacement of RA 21204 during excavation: (a) Displacement versus distance; (b) Displacement versus time.

Table 4. Relationship between time and distance to excavation face and LCF at CL1.

\begin{tabular}{cccc}
\hline Time/h & $\mathbf{2 0}$ & $\mathbf{9 8}$ & $\mathbf{1 8 3 0}$ \\
\hline Distance to the excavation face/m & 30 & 125 & $/$ \\
Distance to the LCF $21204 / \mathrm{m}$ & $/$ & $/$ & 108 \\
\hline
\end{tabular}

Table 5. Relationship between time and distance to excavation face and LCF at CL2 and CL3.

\begin{tabular}{ccccc}
\hline Time/h & $\mathbf{5 0}$ & $\mathbf{1 6 0}$ & $\mathbf{1 6 0 0}$ & $\mathbf{1 8 8 0}$ \\
\hline Distance of CL2 to the excavation face/m & 56.5 & 157.5 & $/$ & $/$ \\
Distance of CL3 to the excavation face/m & 55 & 156 & $/$ & $/$ \\
Distance of CL2 to the LCF 21204/m & $/$ & $/$ & 101 & 43 \\
Distance of CL3 to the LCF 21204/m & $/$ & $/$ & 102.5 & 44.5 \\
\hline
\end{tabular}




\subsection{Displacements of the Roadway}

Surface displacement of the roadway was monitored during excavation and mining at $\mathrm{S}+31 \mathrm{~m}$ and $\mathrm{S}+66 \mathrm{~m}$, respectively.

Figure 16 shows the displacement profiles of the roof and sidewalls during excavation. Displacements increased rapidly initially, then continued to increase slowly, and finally stabilized. Maximum roof and sidewall-to-sidewall displacements were 10 and $16 \mathrm{~mm}$, respectively. When the distance from the excavation face was about $50 \mathrm{~m}$ (Figure 15a) on the 2nd day (Figure 15b) after the start of excavation, roof and sidewall-to-sidewall displacements were 8 and $10 \mathrm{~mm}$, respectively. This represented 80 and 62.5 percent of the maximum roof and sidewall-to-sidewall displacements, respectively. Roof and sidewall-to-sidewall displacement rates were 4 and $4.5 \mathrm{~mm} /$ day, respectively. The area within $50 \mathrm{~m}$ from the excavation face was the most severely disturbed, which is consistent with the data obtained from the monitoring of axial loads. The displacement rate was very small in the area between 50 and $125 \mathrm{~m}$ from the excavation face, equivalent to the period between the 2nd and 5th days after the start of excavation. Substantial improvement in the stability of RA 21204 could be visually observed (Figure 16).

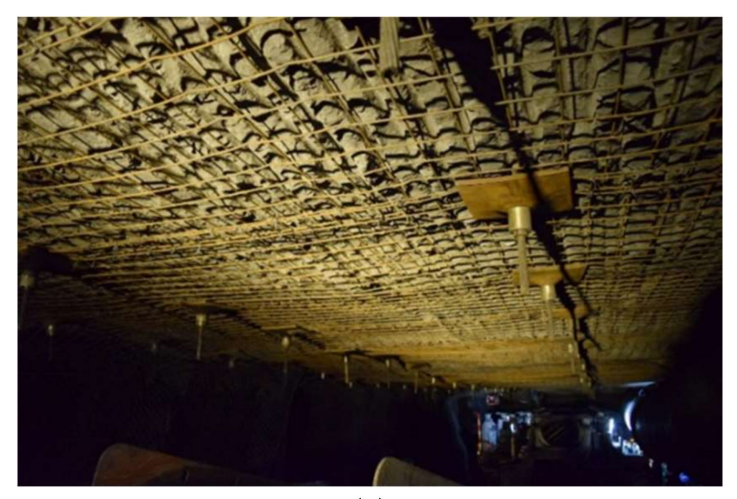

(a)

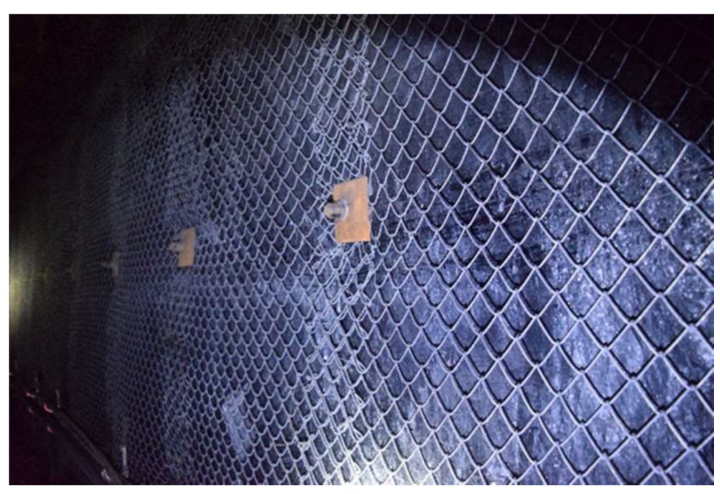

(b)

Figure 16. Photos of the roadway during excavation: (a) roof; (b) sidewall. Note: Photos were taken at $\mathrm{S}+68 \mathrm{~m}$ where the distance from the excavation face was $100 \mathrm{~m}$.

Average excavation speed has increased by $47 \%$, from 17 to $25 \mathrm{~m} /$ day. Moreover, the maximum excavation speed ( $31.5 \mathrm{~m} /$ day) has increased by $85.3 \%$.

Displacement and the displacement rate experienced an overall upward trend as the working face approached the monitoring stations (Figure 17). Mining of LCF 21204 had a greater impact on the roof and floor than on the sidewalls. For instance, at a distance of $40 \mathrm{~m}$ from LCF 21204, roof-to-floor displacement increased from 6 to $30 \mathrm{~mm}$ while sidewall-to-sidewall displacement only increased from 5 to $23 \mathrm{~mm}$. Roof-to-floor and sidewall-to-sidewall displacement rates suddenly increased to 9 and $13 \mathrm{~mm} /$ day, respectively. The area within $40 \mathrm{~m}$ from the excavation face was the most severely disturbed, with slight disturbances extending across an area of up to $100 \mathrm{~m}$ from the excavation face. Deformation characteristics during mining were considerably different from those observed during excavation.

After excavation, a thick anchorage layer was formed in the roof thanks to the rapid active support of the long flexible bolts. It also helped to reduce deformation of the sidewalls. Generally, deformations were small and have been effectively controlled. The performance of the support system was excellent (Figure 18). 


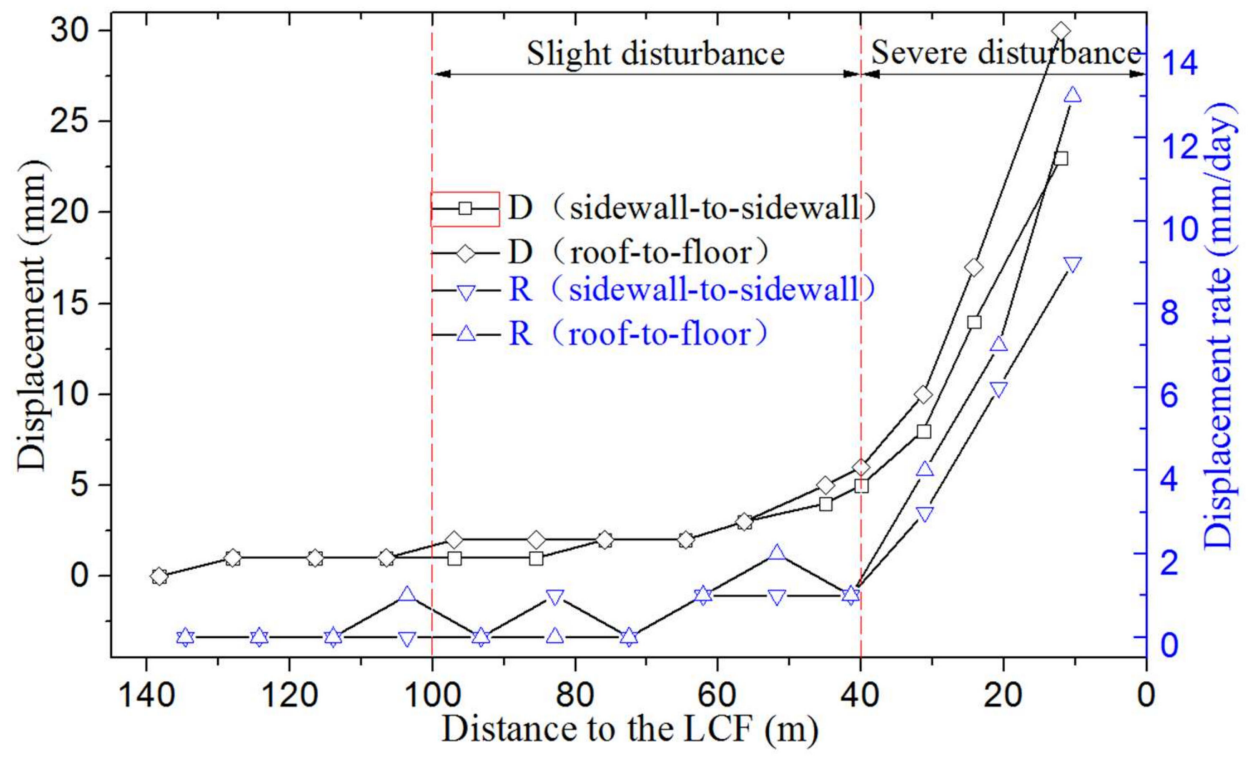

Figure 17. Surface displacement of RA 21204 during mining.

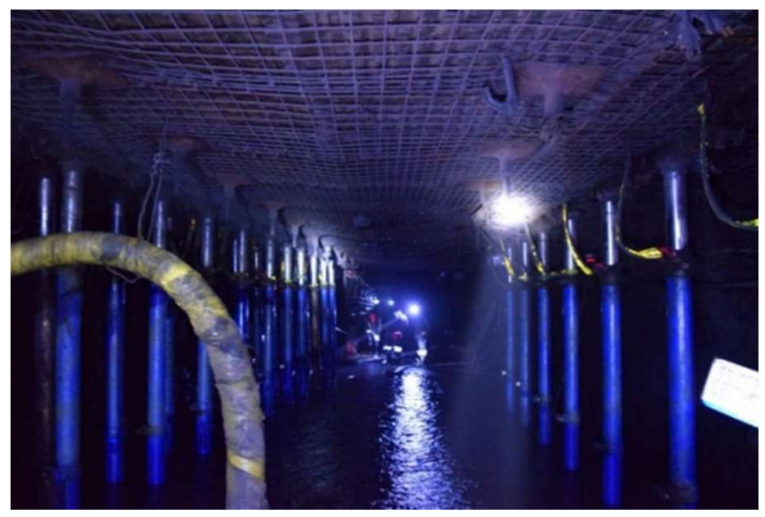

(a)

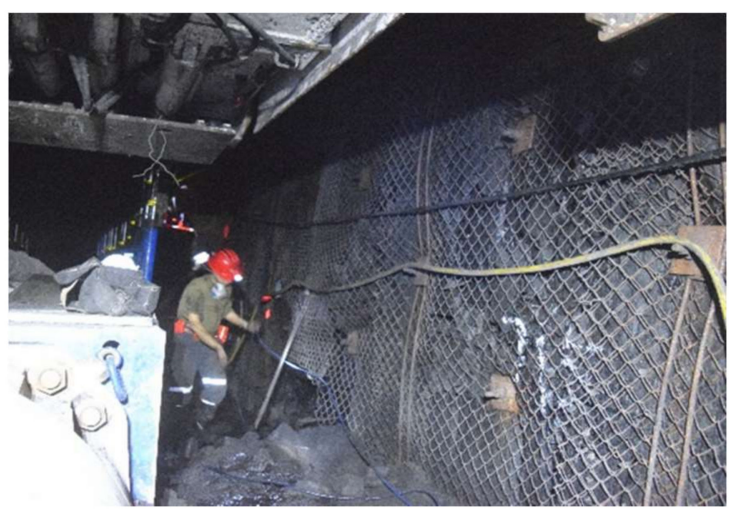

(b)

Figure 18. Photos of the roadway during mining: (a) roof; (b) sidewall. Note: Photos were taken at locations close to LCF 21204.

\subsection{Fracture Development in the Surrounding Rock Mass of the Roof}

Figure 19 shows the locations of the 10-m boreholes used for monitoring fracture development in the roof during excavation and mining. Borehole images indicate that the rock mass in the roof remained intact up to 5-6 $\mathrm{m}$ into the borehole. Figure 20 shows images from the roof surface up to $6 \mathrm{~m}$ into the borehole. The numbers in the figure indicate distance from the roof surface. For example, the image at $2.0 \mathrm{~m}$ corresponds to the rock mass located at $2 \mathrm{~m}$ from the roof surface within the surrounding rock.

Borehole 1 was used to monitor fracture development during excavation (Figure 20a). Two fissures were observed at 0.15 and $0.6 \mathrm{~m}$ from the roof surface, and one fracture zone was recorded at 0.4 to $0.5 \mathrm{~m}$ from the roof surface (Figure 20a). In addition, two ultra-thin coal seams were found at 2.0 and $3.6 \mathrm{~m}$ from the roof surface. Fractures mainly occurred in the area close to the roof surface, and did not extend into the deep rock strata.

Borehole 2 was used to monitor fracture development during mining (Figure 20b). In contrast to borehole 1, fissures were observed at a distance of up to $1.4 \mathrm{~m}$ from the roof surface (Figure 20b). This illustrated that the support system effectively formed a thick reinforced anchorage zone in the roof, 
thereby greatly improving the bearing capacity of the roof. The rock mass within $0.2 \mathrm{~m}$ of the roof surface was extremely broken. There were nine fissures in borehole 2 compared with only two in borehole 1. Eight of the fissures in borehole 2 were located within $1.0 \mathrm{~m}$ of the roof surface. There were two ultra-thin coal seams without fissures at $2.15 \mathrm{~m}$ (100 mm thick) and $3.6 \mathrm{~m}$ (100 mm thick) from the roof surface. Thus, compared with the previous bolt and cable support system, the new active support system of long flexible bolts pretensioned to high levels effectively formed a thick reinforced anchorage zone in the roof, which controlled deformation and fracture development of the surrounding rock during excavation and mining.

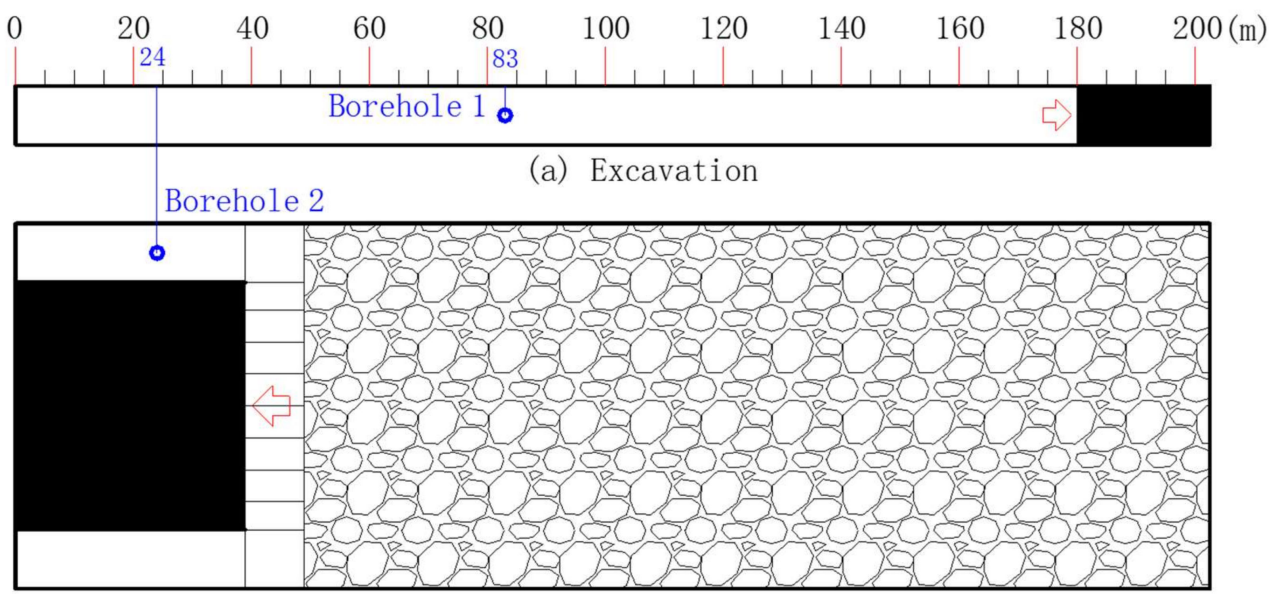

(b) Mining

Figure 19. Locations of the boreholes used for monitoring fracture development in the roof: (a) Images from borehole 1 were taken at $97 \mathrm{~m}$ behind the excavation face; (b) Images from borehole 2 were taken at $25 \mathrm{~m}$ ahead of the LCF in the area of strong disturbance.

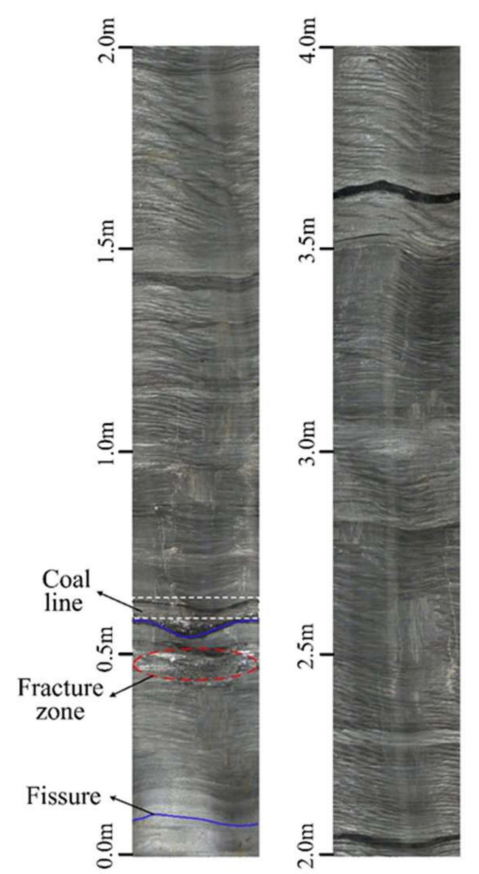

(a) Borehole 1

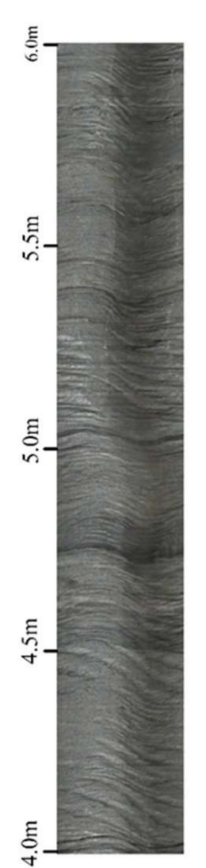

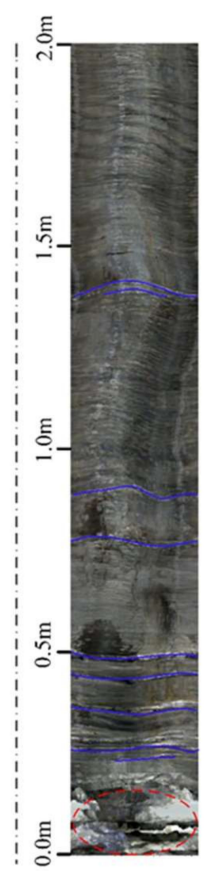

约

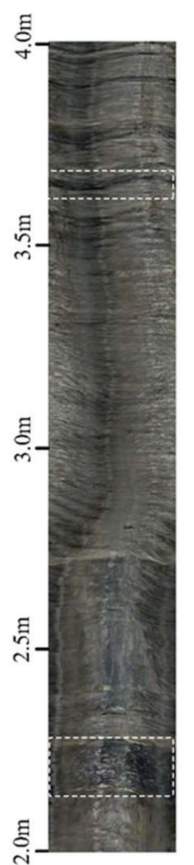

(b) Borehole 2

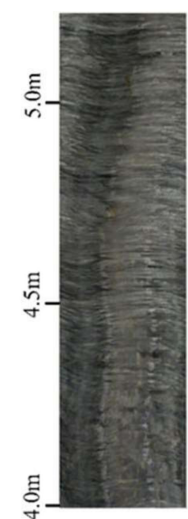

Figure 20. Borehole images of the roof during: (a) excavation, (b) mining. Note: Blue lines indicate the locations of fissures, red ellipses indicate fracture zones, and white rectangles mark coal lines. 


\section{Conclusions}

For large underground coal mines producing 10 million tons a year, rapid excavation and stability of deep roadways are pivotal to ensure sustainable, safe, and efficient production. This paper presents a case study on the stability of a deep roadway in an underground coal mine in Inner Mongolia, China. The research results were obtained from field measurements and engineering practices. They provide practical reference and guidance for other coal mines with similar geological conditions. Some insights and conclusions are summarized as follows.

(1) In situ stress measurements indicated that high stress was one of the main factors of roadway instability. The previous support system employed short bolts and cables, which were insufficient to achieve synergetic effects. This resulted in roadway instability and failure, which prevented rapid excavation.

(2) Compared with the previous support system of short bolts and cables, the new support system consisting of long flexible bolts pretensioned to high levels and spaced at large intervals was simpler to install, required fewer bolts, and resulted in higher excavation speed. Using the new system, a maximum excavation speed of up to $31.5 \mathrm{~m} /$ day was achieved. This represented an $85.3 \%$ increase compared with the maximum excavation speed achieved under the previous support system (17 m/day).

(3) The new support system formed a thick reinforced anchorage zone, which greatly improved the bearing capacity of the roof. Field measurements indicated that the new system effectively controlled deformation and fracture development of the surrounding rock during excavation and mining. Maximum displacements of the roof during excavation and mining were 10 and $30 \mathrm{~mm}$, respectively. During mining, fissures propagated up to only a depth of $1.4 \mathrm{~m}$ into the surrounding rock mass of the roof.

(4) The axial load on the flexible bolts was used as an important index to predict and monitor the safety level of the roof. The level of pretension on the bolts determines the sensitivity of the bolt to stress changes in the rock mass and is reflected by the speed at which axial loads on the bolts increase. Pretension levels also determine the ultimate strength of the bolt. According to field measurements, the evolution of axial loads can be divided into the surge, stable, and fluctuation stages. Axial loads experienced a sharp upward trend during the surge stage as a result of slight deformations caused by excavation operations. This active response of the bolts is beneficial to the prevention of large deformations and failure of the roof during excavation and mining.

Acknowledgments: This work was financially supported by the National Natural Science Foundation of China (Grant No. 51704277 and No. 51674244), the Fundamental Research Funds for the Central Universities (Grant No. 2017CXNL01, No. 2017CXTD02, and No. 2018QNA27), the Project funded by China Postdoctoral Science Foundation (Grant No. 2017M621874), and a Project Funded by the Priority Academic Program Development of Jiangsu Higher Education Institutions. The authors are grateful to the staff at the Hulusu Coal Mine for their assistance during the field measurements. The authors thank Tina Tin, from Liwen Bianji, Edanz Group China (www.liwenbianji.cn/ac), for editing the English text of a draft of this manuscript.

Author Contributions: All of the authors contributed extensively to the work. Zhengzheng Xie, Nong Zhang, and Deyu Qian proposed key ideas. Nong Zhang and Changliang Han provided practice guidance in the research process. Zhengzheng Xie and Changliang Han contributed to field measurements. Zhengzheng Xie, Deyu Qian, and Changliang Han analyzed the data. Zhengzheng wrote the paper. Deyu Qian, Changliang Han, Yanpei An, and Yang Wang modified the manuscript.

Conflicts of Interest: The authors declare no conflict of interest.

\section{References}

1. Peng, S.; Zhang, B.; Wang, T. China's coal resources: Octothorpe shaped distribution characteristics and sustainable development strategies. Eng. Sci. 2015, 17, 29-35.

2. Qian, D.; Zhang, N.; Pan, D.; Xie, Z.; Shimada, H.; Wang, Y.; Zhang, C.; Zhang, N. Stability of deep underground openings through large fault zones in argillaceous rock. Sustainability 2017, 9, 2153. [CrossRef] 
3. Xu, Z.; Gao, S.; Cui, S.; Sun, Y.; Chen, Z. Hydro-geological basic and practice for water-preserved mining in ecologically vulnerable area: A case study in Hami coalfield. J. China Coal Soc. 2017, 42, 80-87.

4. Kang, H.P. Support technologies for deep and complex roadways in underground coal mines: A review. Int. J. Coal Sci. Technol. 2014, 1, 261-277. [CrossRef]

5. Kang, H.P. Sixty years development and prospects of rock bolting technology for underground coal mine roadway in China. J. China Univ. Min. Technol. 2016, 45, 1071-1081.

6. Wang, X. Current situation of rapid excavation technology and equipment in coal mine roadway in China. Coal Mine Mach. 2017, 38, 1-3.

7. Wang, Y.; Shan, R.; Cai, W. Factor analysis on factors influencing on driving speed of coal roadway in Xishan mining area. J. China Coal Soc. 2011, 36, 925-929.

8. Çopur, H.; Tunçdemir, H.; Bilgin, N.T.; Dinçer, T. Specific energy as a criterion for the use of rapid excavation systems in Turkish mines. Trans. Inst. Min. Metall. 2013, 110, 149-157. [CrossRef]

9. Nnaurato, N.; Mancini, R.; Rondena, E.; Zaninetti, A. Forecasting and effective TBM performances in a rapid excavation of a tunnel in Italy. In Proceedings of the 7th ISRM Congress, Aachen, Germany, 16-20 September 1991.

10. Jiang, Y.S.; Chen, L.H.; Ju-Gen, F.U. Discussion on organization optimization of roadway rapid excavation in second construction period of mine. J. Anhui Univ. Sci. Technol. 2011, 81, 553-557.

11. Zhang, D. Development and application on rapid driving system. Coal Sci. Technol. 2015, 43, 96-99.

12. Hu, S.T.; Nie, B.S.; Liu, M.J.; Liu, Y.W.; Li, X.C.; Guo, J.H. Research on rapid excavation technology of roadway in coal seam with the risk of coal and gas outburst. Adv. Mater. Res. 2012, 524-527, 325-329. [CrossRef]

13. Mishra, A.K.; Sen, A.; Sain, D. Innovative developments in drilling and blasting techniques for rapid excavation of drivages in mines. J. Mines Met. Fuels 2013, 61, 194-201.

14. Wang, Z. Bolter Miner Quick Tunneling Technology and Process in High Gas Thick Coal Seam. Master's Thesis, China University of Mining and Technology, Xuzhou, China, 2014.

15. Yuan, W.H. Rapid excavation technology by drilling and blasting and its application in hard rock roadway. In Proceedings of the International Conference on Multimedia Technology, Hangzhou, China, 26-28 July 2011.

16. Yang, R.S.; Cao, W.J.; Liu, G.Q.; Bai, X.S.; Guo, D.M. Rapid excavation research of half coal rock lane in Liu-wan mine. Appl. Mech. Mater. 2012, 170-173, 418-423. [CrossRef]

17. Goel, R.K.; Jethwa, J.L.; Paithankar, A.G. Tunnelling through the young Himalayas-A case history of the Maneri-Uttarkashi power tunnel. Eng. Geol. 1995, 39, 31-44. [CrossRef]

18. Zhang, M.; Shimada, H.; Sasaoka, T.; Matsui, K.; Dou, L. Evolution and effect of the stress concentration and rock failure in the deep multi-seam coal mining. Environ. Earth Sci. 2014, 72, 629-643. [CrossRef]

19. Seedsman, R. The stress and failure paths followed by coal mine roofs during longwall extraction and implications to tailgate support. In Proceedings of the 20th International Conference on Ground Control in Mining, Morgantown, WV, USA, 7-9 August 2001.

20. Li, H.; Lin, B.; Hong, Y.; Gao, Y.; Yang, W.; Liu, T. Effects of in-situ stress on the stability of a roadway excavated through a coal seam. Int. J. Min. Sci. Technol. 2017, 27, 917-927. [CrossRef]

21. Yang, S.Q.; Chen, M.; Jing, H.W.; Chen, K.F.; Meng, B. A case study on large deformation failure mechanism of deep soft rock roadway in Xin'An coal mine. Eng. Geol. 2016, 217, 89-101. [CrossRef]

22. Li, C.; Wang, Z.; Liu, T. Principle and practice of coupling support of double yielding shell of soft rock roadway under high stress. Int. J. Min. Sci. Technol. 2014, 24, 513-518. [CrossRef]

23. Ding, X.; Weng, Y.; Zhang, Y.; Wang, T.; Rao, Z. Stability of large parallel tunnels excavated in weak rocks: A case study. Rock Mech. Rock Eng. 2017, 50, 2443-2464. [CrossRef]

24. Shen, B.; King, A.; Guo, H. Displacement, stress and seismicity in roadway roofs during mining-induced failure. Int. J. Rock Mech. Min. Sci. 2008, 45, 672-688. [CrossRef]

25. Shen, B.T. Coal mine roadway stability in soft rock: A case study. Rock Mech. Rock Eng. 2014, 47, $2225-2238$. [CrossRef]

26. Qian, D.; Zhang, N.; Shimada, H.; Wang, C.; Sasaoka, T.; Zhang, N. Stability of goaf-side entry driving in 800-m-deep island longwall coal face in underground coal mine. Arab. J. Geosci. 2016, 9, 1-28. [CrossRef]

(C) 2018 by the authors. Licensee MDPI, Basel, Switzerland. This article is an open access article distributed under the terms and conditions of the Creative Commons Attribution (CC BY) license (http:/ / creativecommons.org/licenses/by/4.0/). 